Yu. Pliska, Doctor of Pedagogical Sciences, Assistant Professor

Warsaw University of Life Sciences, Warsaw, Poland

ORCID 0000-0002-4752-8641

\title{
PERSONALITY OF CREATIVE TEACHER IN FOREIGN THEORY AND PRACTICE
}

The article focuses on the fact that creativity for the teacher is a relevant component of his professional activity, a way of self-realization, support in the development of the personality of others.

The diversity of pedagogical activity which is directed not only at creation of pedagogical technologies, but also at values of pupils is the essential basis of development of personality of the creative teacher is proved.

The content and structure of personality of a creative teacher in foreign theory and practice are investigated. It is proven that a creative product is the result of a specific human action that is influenced by a particular environment. personality, intelligence and temperament, as well as body structure, character traits, habits, attitudes, self-esteem, value systems, mechanisms of protection and behavior.

The main components of a teacher's professional activity, in particular his knowledge and skills, namely didactic, communication, organizational, scientific and creative, are distinguished.

It is found that the important features of a creative teacher are the awareness of their own creative abilities and creativity, belief in themselves, respect for others, empathy, enthusiasm and expression, courage in accepting risky and non-standard situations, competence and curiosity associated with a high level of intelligence and self-perfection, attractiveness and originality, artistic sense and creative imagination, 'open mind' and independence of thinking, tolerance, self-organization, activity, vitality and flexibility at work.

It is proved that the creative teacher is characterized by high level of pedagogical creativity, possesses the traits of creative personality, motives, abilities that contribute to successful creative pedagogical activity.

Keywords: personality, creative teacher, creativity, experience, professional activity, pedagogical technologies, value.

Ю. Плиска, д-р пед. наук, адъюнкт

Варшавский университет естественных наук, Варшава, Польша

ORCID 0000-0002-4752-8641

\section{ЛИЧНОСТЬ ТВОРЧЕСКОГО УЧИТЕЛЯ В ЗАРУБЕЖНОЙ ТЕОРИИ И ПРАКТИКЕ}

В статье акцентировано внимание на том, что творчество для учителя является актуальной составляющей его профессиональной деятельности, способом самореализации, поддержкой в развитии личности других.

Доказано разнообразие педагогической деятельности которая направлена не только на создание педагогических технологий, но и на ценности учащихся является существенным основанием развития личности творческого учителя.

Исследовано содержание и структуру личности творческого учителя в зарубежной теории и практике. Доказано, что творческий продукт является результатом конкретного действия человека, на которого влияет определенную среду. личность, интеллект и темперамент, а также структура тела, черты характера, привычки, взгляды, самооценка, ценностные системы, механизмы защиты и поведение.

Выделены основные составляющие профессиональной деятельности учителя, в частности его знания и умения, а именно дидактические, коммуникационные, организационные, научные и творческие.

Выяснено, что важными чертами творческого учителя является осознание собственных творческих способностей и креативности, вера в себя, уважение для других, эмпатия, энтузиазм и экспрессия, мужество в принятии рискованных и нестандартных ситуаций, компетентность и интерес связанные с высоким уровнем интеллигенции и самосовершенствованием, привлекательность и ориаинальность, художественный смысл и творческое воображение, «открытый ум" и независимость мышления, толерантность, самоорганизация, активность, жизненность и гибкость в работе.

Доказано, что творческий педагог характеризуется высоким уровнем педагогического творчества, имеет черты личности, мотивы, способности, которые способствуют успешной творческой педагогической деятельности.

Ключевые слова: личность, творческий учитель, творчество, опыт, профессиональная деятельность, педагогические технологии, ценность.

УдК 378.091:81'255

DOI: https://doi.org/10.17721/2616-7786.2018/4-1/7

Shi Zhai, Doctor of Philosophy in pedagogy, Director of China Leadership Scientific Research Association, Beijing, China, ORCID iD 0000-0001-7024-5685

\section{ORIENTING POINTSOF MODERN POLYCULTURAL EDUCATION}

The article deals with the orienting points of multicultural education in the modern educational space. Emphasis is placed on the social upbringing of an individual in the context of cultural dialogue; education of tolerance and taking into account the religious and ethnic culture of the individual; mastering the universal values of world and national culture; fostering a culture of international communication. The author focuses on the main features of multicultural education as an important way of forming certain social-educational and value-oriented inclinations, communicative and empathic skills that allow a person to carry out intercultural interaction, and to show understanding of other cultures, tolerance towards them.

On the basis of the conducted research the author's vision of the essence of multicultural education of the modern personality is formed, in particular purposeful socialization of the personality, which necessarily includes assimilation of samples and values of world culture, cultural-historical and social experience of different countries and peoples; formation of social-attitudinal and value-oriented qualities of a person capable of effective intercultural communication, as well as development of tolerance towards other countries, peoples, cultures and social groups; active social interaction. with representatives of different cultures while maintaining their own cultural identity.

The goals, principles, functions of multicultural education in the theory and practice of educational process are considered.

Keywords: multicultural education, tolerance, multicultural environment, dialogue of cultures, orienting points, approaches, principles, functions.

Introduction. The 21st century is an era of radical change, the time of co-operation between nations and socalled 'globalization', a century of new culture and the introduction of technologies that require individuality at the level of understanding and acceptance of modern opportunities. This enhances the changes in education aimed at preparing the younger generation of youth for life in a multicultural environment, for dialogue and intercultural interaction, the ability to communicate and cooperate with people of different nationalities, races, religions, to understand and appreciate the originality of cultures, to realize themselves mutual respect, interaction, cooperation. 
Analysis of recent research and publications. Aspects of the problem of multicultural education were reflected in the works of researchers: I. Bakhov, V. Bolharina, L. Honcharenko, V. Kuzmenko, I. Loshchenova, N. Chernukha.

The purpose of the article is to explore the orienting points of multicultural education in the context of globalization.

The main material. Multicultural education is considered today as a process of involving students and students in ethnic, national and world culture; how to develop and shape the ability to live in a multicultural world; as a process of a new generation's upbringing with planetary thinking [1].

Multicultural education is based on upbringing and education in the context of cultural dialogue; education of tolerance and religious-ethnic culture; assimilation of universal values of world and national culture; fostering a culture of international communication. Thus, multicultural education is characterized by the presence of a humanistic educational ideology and a leading personality-oriented type of education. Higher value of multicultural education is the person, the person [2].

At present, the prominent features of multicultural education are the formation of a person capable of active and effective life in a multinational and multicultural environment, possessing a developed sense of understanding and respect for other cultures, the ability to live in peace and harmony with people of different nationalities, races, beliefs. In these circumstances, multicultural education, on the one hand, promotes the ethnic identification and formation of cultural identity of young people, and on the other hand, impedes their ethnic and cultural isolation from other countries and peoples [3].

It should be noted that an important social determinant of the development of multicultural education is the intensive development of integration processes, as an important component of the development of the modern world, as well as the desire of Ukraine and other countries to integrate into the world and European socio-cultural and educational space, while maintaining the national identity. Integration processes help to create an international multilingual environment in which national languages have equal rights [4].

The development of multicultural education is conditioned not only by modern historical and socio-cultural prerequisites, but also by several traditions of national and foreign philosophy, pedagogy, psychology.

The analysis and research of the complex of historical and socio-cultural factors, as well as the philosophicalpedagogical and psychological determinants allow us to distinguish the most common approaches to understanding the essence of multicultural education.

Consider the first of them acculturation. This approach is associated with the emergence of the term 'multicultural education'. Within the framework of the acculturation approach, a significant part of foreign studies is of the opinion that multicultural education should be oriented towards the culture of immigrants. German researcherUrsula BoosNünning notes that the theoretical interpretation of the concept of 'migrant culture'is at present the central, but not yet solved, task of researchers in migration processes. Multicultural education should include the study of the traditions of the native culture, the process of processing these traditions within the framework of a new culture, as confrontation with changed living conditions necessitates the development of new cultural guidelines [5]. This formulation of the objectives of multicultural education implies the need for a serious study of migrant culture but avoids such pedagogical norms as 'mutual cultural enrichment'. Within the framework of the acculturation approach, the issue of cultural identity (a set of cultural forms, traits, characteristics) of a person is central. When considering it, multicultural education is based first and foremost on existentialist ideas of free choice and transcendental perceptions of man by man [4].
It should be noted that in domestic studies, the acculturation approach has not received much distribution, because for Ukraine it is more relevant to preserve and enrich both Ukrainian culture, which acts in our country as the dominant culture and national and cultural identity of other peoples that inhabit Ukraine.

It is advisable to consider that in a multicultural society the educational space should be built taking into account the modern socio-cultural environment. This problem is actively developed today in domestic and foreign science.

Recently, a dialogue approach based on the ideas of openness, dialogue of cultures, cultural pluralism has become of great importance. The philosophical and methodological basis of this approach is this understanding of dialogue, when all philosophical systems are not discarded but they are interacted and coexist. The humanism of such interaction is that every cultural subject must experience incompleteness of being before the endless diversity of the entire world culture. In such circumstances, only dialogue between them can be recognized as the only reasonable and yet moral way of truly uniting different cultures [6].

Analyzing the research of scientists, it can be argued that the relationships between cultures can be different: a) utilitarian attitude of one culture to another; b) the attitude of rejection of one culture by another; c) relations of interaction, mutual enrichment, that is, the relation of cultures to each other as equal subjects.

Therefore, in order to understand how the mechanism of cultural dialogue works, it is methodically useful to imagine a culture in the form of a system consisting of several subsystems. In order to interact with another culture, a corresponding subsystem is created, in which there is a complex process of harmonizing (adapting) one's own cultural codes with those of another culture. Such processes occur in both cultures that enter into dialogue, each of which creates a special subsystem for dialogue from the other. The failure of cultural adaptation leads to the curtailment of the activity of this subsystem, not of the whole culture system. Successful promotion of cultural adaptation can lead to a broader impact of already modified external cultural influences on the entire cultural system.

An important philosophical and cultural basis of multicultural education is the thesis of cultural pluralism, which is intended to reflect in a specifically refracted (cultivated) form the multifaceted and contradictory social reality. We must recognize that the world is a difference, and therefore a unity of cultural diversity is necessary. Dialogue, which is recognized as a fundamental principle of the life of cultures, points to the essential need of one culture for another.

In the process of multicultural education, we are confronted with the differentiated unities of the culture of the past, present and future, which can only be understood in their historical continuity and interconnection. Each of these unities is 'three-layer', each has its 'fixed', its actual and its potential content (meaning, meaning). The potential meaning of the past and the 'fixed' prediction of the future are found in the actual content of the present. The 'fixed' content of this is largely known in the relevance of the previous past, and the potential meaning of the present is reflected in one way or another in the relevance of the content of the future that follows the present. Thus, the idea of culture 'as an open differentiated unity, makes it possible to comprehend a number of typologically distinct and historically distant cultures as a whole-semantic unity that continues in time, as some continuous, historically changing, contradictory, but intrinsically integral continuum. culture '[2].

Within the framework of a dialogical approach, scholars view multicultural education as 'a modern tendency in the world process, which affirms the idea that many independent independent entities are at the heart of world civilization' [1; $2 ; 3 ; 4]$. Revealing the essence of multicultural education, 
the researchers emphasize that it is aimed at preserving and developing all the diversity of cultural values, norms, patterns and forms of activity existing in this society, and is based on the principles of dialogue and interaction between different cultures. Multicultural education exists in an international and inter-ethnic context, as the interconnection of different cultural environments in education.

The second position is taken by another group of scholars, for example, criticizing the acculturation approach to multicultural education, $\mathrm{H}$. Dmitrievnotes that many researchers call multicultural education that essentially reflects issues related to the normalization of relations between ethnically diverse groups and individuals. In multicultural education, he sees not only 'a way to counter racism, prejudice, ethnocentrism, hatred based on cultural differences' but also 'a pedagogical attempt to help understand one's culture, the role of generalizations and stereotypes in communicating between different cultures,' to identify yourself [7].

There is another definition of multicultural education as a pedagogical response to the reality of a multicultural society, as an open activity-oriented concept that perceives all social changes and initiates innovative processes. Multicultural education is seen as contributing to peace education by resolving intercultural conflicts. The author of this concept $(\mathrm{H}$. Pomerin) proceeds from the idea of recognizing the individual differences of each personality and considers multicultural education activity-oriented and open to new knowledge and new experience [1].

It is valuable, in our view, to define the American cultural researcher A. Thomas: 'Multicultural education takes place when a certain person seeks to understand, in communication with people of another culture, their specific system of perception, cognition, thinking, their system of values and actions, to integrate a new one. experience in one's own cultural system and change according to another's culture. Multicultural education encourages, together with the knowledge of another's culture, to analyze the system of one's own culture' [8].

These understandings allow us to distinguish between different levels of multicultural education or the degree of involvement in another's culture: from understanding to borrowing some of the activities and selectively applying them. These levels may correspond to particularstages in the process of multicultural education or may be the end result.

Recently, in the course of psychological and pedagogical discussions on the problems of multicultural education, concepts and separate theoretical positions emerge, which can be conditionally combined within the meaningful limits of a social and psychological approach, which has not been yetfully formed in science. However, it is already possible to distinguish some of its distinctive features, the most important of which is the consideration of multicultural education as a special way of forming certain socialeducational and value-oriented inclinations, communicative and empathic skills, which allow the graduate of secondary and higher school to intensely interact with each other. and show understanding of other cultures, as well as tolerance towards their media [9].

In the tradition of the socio-psychological approach, the concept of so-called 'cultural differences' operates. Its supporters formulate the following goals of multicultural education:

- developing tolerance for others' lifestyles and behaviors based on an understanding of differences in a person's cultural appearance that can lead to conflicts between members of different social strata;

- awareness that cultural differences and other people's cultures as a whole affect the emotional sphere of a person, becoming a source of his or her experiences and needs;

- the development of the ability to differentiate within a foreign culture, the ability to evaluate systems of values and norms by the degree of their historically specific importance for certain activities;

- forming the ability to integrate elements of other cultures into one's own system of thinking and values.

Undoubtedly, solving the problems of multicultural youth education requires strengthening of the multicultural component in the preparation of the future specialist. In this connection, the theoretical proposition of multiculturalism put forward by $\mathrm{H}$. Dmitriev becomes an important component, as an important component of professionalism. Based on this position, future professionals 'must be able to work with culturally diverse people, properly understand human differences, be tolerant of them, be able to establish cultural pluralism in society through their personal actions and words'[7].

Multicultural education is based on the following social and pedagogical principles: education of human dignity and high moral traits; education for the coexistence of social groups of different races, religions, ethnicities; education of tolerance, readiness for mutual cooperation.

The functions of multicultural education include: the formation of ideas about the diversity of cultures and their relationship; awareness of the importance of cultural diversity for the self-realization of the individual; fostering a positive attitude to cultural differences; development of interoperability of carriers of different cultures on the basis of tolerance and understanding.

Multicultural education has three groups of goals, which can be labeled with the terms'pluralism', 'equality', 'unification': respect and preservation of cultural diversity; support for equal rights to education and upbringing; formation and development in the spirit of national, political, economic, spiritual values $[9 ; 10]$.

Thus, the content of multicultural education is built around the following orienting points: sociocultural identification of the individual; mastering the system of concepts and ideas about the multicultural environment; fostering a positive attitude towards the cultural environment; development of social communication skills. An analysis of the main approaches and leading conceptual ideas of multicultural education shows that all these approaches are complementary to each other, and the goals formulated within individual concepts can be considered as a direction of activity of educational institutions at different stages of realization of multicultural education of pupils and students.

Conclusions. On the basis of the above, the author's vision of the essence of multicultural education of pupils and students has been formed: a type of purposeful socialization of students, which provides: at the cognitive level the development of samples and values of world culture, cultural, historical and social experience of different countries and peoples; at the value-motivational level - the formation of social-setting and value-oriented inclinations of young people to intercultural communication and exchange, as well as the development of tolerance towards other countries, peoples, cultures and social groups; at the activity-behavioral level - active social interaction. with representatives of different cultures while maintaining their own cultural identity. This is a priority segment for today's educational environment.

Further research needs forms, methods, technologies of multicultural education in accordance with the challenges of time.

References

1. Bakhov I. S. Dialogue of Cultures in Multicultural Education. [Text] World Applied Sciences Journal 29 (1): 106 - 109, 2014 . DOI: 10.5829 idosi.wasj.2014.29.01.13775

2. Bolharina V., Loshchenova I. Culture and Multicultural Education // Path of Education. Educational press. - 2002. - №1. - P. 2-6.

3. Guk O.F., Chernukha N.M. Priority vectors of modern education O.F. Guk, N.M. Chernukha // Topical issues of socialpedagogy: Collective monograph. - CARICOM, Barbados, 2017. - P. 30-55. Monograph ISBN 978-0-9955865-1-2 
4. Loshchenova I.F. Development of ideas of multicultural education in the world pedagogical thought // Pedagogy and psychology. Educational press. - 2002. - № 1 - 2. - P.68-77.

5. Boos-Nünning U. Admission Lessons, Native Language Lessons, Intercultural Education. Results of a comparative study on teaching foreign children in Belgium, England, France and the Netherlands / Boos-Nünning U., Hohmann M., Reich H.H. - Munich, 1983. - P. 359.

6. Guk O.F. Theoretical studies of the problems of intercultural dialogue O.F.Guk // Intercultural dialogue: the modern paradigm and experience Neighborhood: Sat. Sciences. Art. / Comp. and Sciences. ed.L. Vladykovskaya. Minsk: DIKST BSU, 2014. - P. 45 - 48. ISBN 978-985-491-127-4.

Ші Чжай, д-р філософії в галузі педагогіки,

Директор Китайської асоціації наукових досліджень, Пекін, Китай ORCID iD 0000-0001-7024-5685
7. DmitrievH.D., Multicultural education / H. D. Dmitriev. - M .: National education, 1999. $-208 p$.

8. Thomas, A. Temperament and Development. / A. Thomas, S. Chess. N.Y.,1977.

9. Kuzmenko V.V., Honcharenko L.A. Multiculturalism as a Means of Formation of Personal Perceptions of Interethnic Relations // Proceedings of the International Scientific and Practical Conference'The Problem of Integral Student Personality Development as a Subject of Pedagogical Interaction (Global and Regional Trends)'. - Donetsk. -2004. - P.19-23.

Received November 19, 2018 Reviewed November 26, 2018

\section{ОРІєНТИРИ СУЧАСНОї ПОЛІКУЛЬТУРНОї ОСВІтИ}

В статmі розелядаються орієнтири полікультурної освіти в сучасному освітньому просторі. Акцент зроблено на соціальне виховання особистості в контексті діалогу культур; виховання толерантності та з врахуванням релігійно-етнічної культури особистості; освоєння загальнолюдських цінностей світової та національної культури; виховання культури міжнаціонального спілкування. Автором акцентовано увагу на основних ознаках полікультурної освіти як важливого способу формування певних соціально-настановчих та ціннісно-орієнтаційних схильностей, комунікативних та емпатійних умінь, що дозволяють особистості здійснювати міжкультурну взаємодію, та проявляти розуміння інших культур, толерантність по відношенню до їх носіїв.

На основі проведеного дослідження сформувано авторське бачення сутності полікультурної освіти сучасної особистості, зокрема цілеспрямована соціалізація особистості, що обов'язково включає засвоєння зразків $і$ цінностей світової культури, культурно-історичного та соціального досвіду різних країн і народів; формування соціально-настановних і ціннісно-орієнтаційних якостей особистості, спроможної до ефективної міжкультурної комунікації, а також розвитку толерантності по відношенню до інших країн, народів, культур і соціальних груп; активну соціальну взаємодію. з представниками різних культур при збереженні власної культурної ідентичності.

Розглянуто цілі, принципи, функції полікультурної освіти у теорії і практиці освітнього процесу.

Ключові слова: полікультурна освіта, толерантність, полікультурне середовище, діалог культур, орієнтири, підходи, принципи, функції.

Ши Чжай, д-р философии в области педагогики,

директор Китайской ассоциации научных исследований, Пекин, Китай ORCID iD 0000-0001-7024-5685,

\section{ОРИЕНТИРЫ СОВРЕМЕННОГО ПОЛИКУЛЬТУРНОГО ОБРАЗОВАНИЯ}

В статье рассматриваются ориентиры поликультурного образования в современном образовательном пространстве. Акцент сделан на социальное воспитание личности в контексте диалога культур; воспитание толерантности и с учетом религиозноэтнической культуры личности; воспитание культуры межнационального общения. Автором акцентировано внимание на основных признаках поликультурного образования как важного средства формирования определенных социально-установочных и ценностноориентационных предрасположенностей, коммуникативных и эмпатических умений, позволяющих личности осуществлять межкультурное взаимодействие, и проявлять понимание других культур, толерантность по отношению к их носителям.

На основе проведенного исследования сформировалось авторское видение сущности поликультурного образования современной личности, в частности целенаправленная социализация личности, обязательно включая усвоение образцов и ценностей мировой культуры, культурно-исторического и социального опыта различных стран и народов; формирование социально-установочных и ценностно-ориентационных качеств личности, способной к эффективному межкультурной коммуникации, а также развития толерантности по отношению к другим странам, народам, культурам и социальных групп; активное социальное взаимодействие. $с$ представителями различных культур при сохранении собственной культурной идентичности.

Рассмотрены цели, принципы, функции поликультурного образования в теории и практике образовательного процесса.

Ключевые слова: поликультурное образование, толерантность, поликультурное среда, диалог культур, ориентиры, подходы, принципы, функции.

УДК 371.31:004

DOI: https://doi.org/10.17721/2616-7786.2018/4-1/8

I. Шестопалова, канд. пед. наук, доц. ORCID ID 0000-0002-2027-205X

Х. Потапенко, ст. викладач Міжрегіональна академія управління персоналом, Київ, Україна ORCID ID 0000-0003-3215-6061

\section{СОЦІАЛІЗУЮЧІ АСПЕКТИ ДИСЦИПЛІНИ "ІНОЗЕМНА МОВА"}

Присвячено проблемі соціалізації особистості в процесі вивчення іноземної мови, яка є частиною полікультурної освіти і розглядається як важливий інструмент соціалізації, адаптації особистості в умовах полікультурного суспільства.

Ключові слова: соціалізація; іноземна мова; полікультурна освіта; полікультурна особистість; професійна соціалізація.

Постановка проблеми. Соціалізація особистості в сучасному світі $€$ не простою та досить актуальною проблемою, адже той чи інший рівень соціалізації дозволяють їй з більшою або меншою ефективністю брати участь у житті суспільства, здійснювати соціальні функції і ролі. В сучасній науці поняття соціалізації розуміється як процес входження людини у соціальне середовище і її пристосування до його культурних, психологічних та соціологічних умов. Цей процес $€$ тісно пов'язаним з трудовою, суспільно-політичною та пізнавальною діяльністю людини, отриманням та накопиченням досвіду соціальних відносин,опануванням людиною нових соціальних ролей у різних сферах людської діяльності, формуванням її готовності до соціальних дій. В результаті активної соціалізації молодої людини відбувається її включення у активне життя суспільства, становлення соціальних, громадянських і духовних якостей особистості. 